\title{
ARCHÆOLOGY IN THE LABORATORY
}

\section{A}

CONFERENCE convened by the Council for British Archæology under the title "Archæology in the Laboratory" was held on April 9 in the rooms of the Society of Antiquaries of London, at Burlington House. The proceedings of the conference have only recently become available.

Dr. C. B. M. McBurney (University of Cambridge), in his introduction for the Council, explained that, since its formation in 1944 as the co-ordinating body for archæological research, the Council has been anxious to explore the various possible applications to archæology of the methods and results produced in other scientific fields. A Natural Sciences Panel was accordingly set up and had prepared the "Notes for the Guidance of Archæologists in regard to Expert. Evidence" published in 1947. Not only are the "Notes" now out of date, but also the rapid acceleration of developments in science and technology has made it necessary to re-examine the whole matter with regard to both scope and organization. There is also the reverse aspect, not hitherto considered systematically, where the archæologist could provide the scientific research worker with valuable material in a context that could be precisely defined and is independently datable.

The Council had been considering a proposal, made earlier in the year by Mr. L. Biek (Ministry of Works), to establish a permanent Scientific Research Committee for Archæology. This was, in particular, to facilitate the flow of material sent from archæological excavations for expert examination and to collate the results, and generally to provide a clearing house for information and ideas of mutual value to archæologists and other scientists. The scheme was welcomed by archæologists and, at the suggestion of Sir Mortimer Wheeler (University of London), the Council had decided to invite scientists to give their views on the proposal. Dr. McBurney said he was asking if they considered it to be desirable and practicable, and what they felt about the reciprocal value, to themselves, of this type of work. He was further asking for details of recent advances, and for suggestions about improving and extending investigations as at present carried out, in the principal fields which had been selected for discussion, namely, petrology of stone implements and ceramies, building research, soil science, pollen analysis and other botanical examination, ecology, conchology, animal and human osteology, physical and chemical tests, and metallurgical and corrosion studies.

The following then gave their views: Mr. E. M. Jope (The Queen's University, Belfast), Prof. F. W. Shotton (University of Birmingham), Dr. F. S. Wallis (Bristol Museum), Mr. M. Davies (British Iron and Steel Research Association), Mr. H. Barker, Dr. F. C. Fraser and Dr. K. P. Oakley (British Museum). Dr. N. Davey and Dr. H. G. Midgley (Building Research Station, Department of Scientific and Industrial Research), Mr. R. M. Cook (Cambridge Museum of Classical Archæology), Dr. H. Godwin, Dr. S. K. Runcorn and Dr. J. C. Trevor (University of Cambridge), Mr. T. W. Farrer (Chemical Research Laboratory, Department of Scientific and Industrial Research), Dr. W. H. J. Vernon (recently of the Chemical Research Laboratory), Dr. F. Y. Henderson (Forest Products Research Laboratory, Department of Scientific and Industrial Research), Dr. P. A. Sabine (Geological Survey), Mr. C. F. M. Fryd (Department of the Government Chemist), Prof. R. D. Preston (University of Leeds), Dr. I. W. Cornwall, Prof. F. W. Jane and Prof. F. E. Zeuner (University of London), Mr. H. H. Coghlan (Newbury Museum), Dr. E. T. Hall (University of Oxford), and Dr. J. S. Weiner (Oxford University Museum).

With certain notable exceptions in the fields of metallurgical and palæomagnetic analysis, where more or less specific schemes are operating to less than capacity and samples are indeed welcome, it seems that there is a general lack of man-power if not, in most cases, of equipment. Nevertheless, work in all the other fields is proceeding well. Important advances have been made in applying the use of 'white' X-rays to the study of unknown materials. Pollen analysis has been expanded to include herbaceous plants and to give information about methods of husbandry. Full details were given about a 'general service' in carbon-14 dating, due to begin shortly. The possibility of typifying certain pottery on a physical basis (that is, by making thin sections, etc.) is being examined, and a tentative suggestion was made about relating changes in the submicroscopic structure of wooden remains to the duration of burial under certain conditions.

Although the principles are in most cases fairly well understood, methods of preparing specimens (for example, for charcoal analysis) are sometimes imperfect, or there may be a lack of suitable comparative material in certain specific respects (for example, for matching rocks or bones); both here and in fields not so limited (for example, in counting pollen grains), the work is extremely tedious and time-consuming.

The majority of speakers thus reluctantly, but firmly, refused to accept investigations which were unlikely to help in solving some major problem. Even in the relatively simpler work of chemical analysis, identifying wood, and analysing mortars, isolated queries are discouraged unless submitted through some recognized institution. In the case of mortar analysis, as also with samples for carbon-14 and palæomagnetic examination, correct and careful sampling is essential. Where, as in the majority of cases, this aspect is less important, it is at least necessary to know the context accurately and reliably, because results can only be interpreted in relation to 'neutral' associated material. On the other hand, with problems involving soil and pollen analysis, or the corrosion of metals, it is absolutely vital for the investigator to be present during excavation in order to evaluate all aspects of the site from his point of view and to take his own samples. Archæological evidence is of great importance to research in botany, geophysics and metallic corrosion, and can be of great value to building research, soil science, human osteology, and the submicroscopic study of wood.

The suggestions made for improvement fall into four general groups. First, more workers and more (suitably selected) material for analysis and reference constitute major requirements. Several speakers stressed that such work, in general, is not appropriately recognized or paid, and consequently the 
number of, say, geologists interested in archæological problems will always be very small. It would help if such small groups could meet regularly to discuss problems and progress. It was suggested that museum staff, in particular, should be approached with the view of interesting them more in this type of work. In Denmark, pollen analysts, petrologists and archæologists are successfully collaborating at the National Museum, and it was felt that the volume of such work in Britain would remain small until some similar scheme were put into operation.

It was further stressed that definite instructions should be issued to prevent the destruction or loss of valuable material (particularly botanical and osteological) and records (for example, of the preservation of buildings), and that these should be centrally stored and suitably catalogued ; so that even if there should be no facilities for immediate examination, the material would be available later. Other sug. gestions included the preparation of sets of slides of petrological specimens from archæological finds, and organic-carbon assays (perhaps at university centres) to determine whether a sample is suitable for carbon-14 analysis. It is-as so very frequently in scientific work-most important to develop a battery of techniques for any one type of problem in order to obtain reliable results; thus no fewer than six methods were used in the recent investigation of the Piltdown mandible.

Secondly, it is important that archæologists should frame specific questions to accompany their material ; this would considerably ease the invest. igators' burden, and serve to prevent friction and loss of time. In certain cases (for example, bones) excessive cleaning prior to dispatch from the site is undesirable.

Thirdly, it was obvious from all that had been said that the closest co-operation between archæologists and scientists at all stages is essential, not forgetting regular contact between, for example, the petrologists themselves who are engaged on archæological work.

Finally, this aspect becomes vital when (as in most cases) the problem has to be considered statistically. The examination of human bones can take on a wider significance only when its results can be related geographically. Only the archæologist can tell, in the last instance, which copper implements form a homogeneous series suitable for metallurgical analysis in attempting to trace the ores that have provided the metal ; sometimes museum specimens of ores, selected on a different basis, may not include inferior material that might well have been used by early metal-workers.

In carbon-14 determinations, quite apart from the statistical errors due to equipment and method, structural differences between young and mature wood, and contamination both during and after burial may be expected to affect the results. A number of such 'rogues' have in fact been encountered, and single or even duplicate estimations may well be more misleading than helpful unless considered on a wider statistical basis. This calls for full and accurate publication of results, and the Council was urged to oppose firmly any unilateral 'editing' of scientific appendixes in archæological journals. It further points clearly to the need for planned research and, ultimately, for an Archæological Research Institute embracing all aspects and capable of both research and routine work. Concrete proposals for such a body, it was felt, should be worked out and submitted through the Council to the appropriate quarters as soon as possible.

In one of the concluding remarks the hope was expressed that, as a result of the conference which had thrown this aspect into relief, something might be done to make it easier for archæologists and scientists to understand one another; so that the archæologist could come to know the limitations of scientific techniques, and the scientist in his turn would be able to appreciate archæological requirements. The president, Dr. D. B. Harden, in thanking members of the conference on behalf of the Council, had no doubt that the latter would be glad to do what it could, particularly about 'vetting' material sent for expert examination, in order not to strain the limited resources available. He said that he and other archæologists present had been most encouraged by the support given to the conference; if an Archæological Research Institute still seemed a long way off, it was well worth while working towards it in the best possible way.

As reported in Nature of October 9, p. 677, a Scientific Research Committee for Archæology has now been formed by the Council. Further details may be obtained from the Assistant Secretary, Council for British Archæology, 10 Bolton Gardens, London, S.W.5.

L. BIER

\section{PHYSICS OF CLOUDS AND PRECIPITATION}

A $\mathrm{N}$ international symposium was held at the Federal Institute of Technology, Zurich, during October 4-6, under the auspices of the Swiss Federal Commission for the Study of Hail Formation and Prevention, to discuss recent developments in the physics of clouds and precipitation and in the artificial modification of clouds. After the delegates had been welcomed by Prof. R. Sänger, president of the Commission, opening addresses were given by H. Dessens (France) on some theories of cloud nucleation submitted to experimental test, and by B. J. Mason (Great Britain) on the physics of natural precipitation processes.

M. Dessens described studies at the Pûy de Dome of the freezing of water droplets and the growth of ice crystals in the laboratory. The droplets, supported on spiders' threads, were suspended in a cold chamber on the stage of a microscope. Although large drops generally froze at higher temperatures than small ones, he obtained no elear-cut relation between drop size and freezing temperature because the freezing mechanism appeared to be propagated along the thread. However, large drops could be maintained at temperatures above $-12^{\circ} \mathrm{C}$. for many minutes without freezing.

The seeding of natural supercooled stratus clouds with silver iodide produced ice crystals if the temperature was below $-4^{\circ} \mathrm{C}$. and was often followed by precipitation and partial dissipation of the cloud. The seeding of similar clouds with 'dry ice' generally resulted in overseeding in the neighbourhood of the source, but precipitation and dissipation of the cloud did not follow. Large-scale seeding with silver iodide was carried out in the Pyrenees during 1951-53, but the effect on the rainfall was inconclusive. Clouds in this region tended to glaciate naturally if their summits were colder than $-15^{\circ} \mathrm{C}$.

Mr. Mason reviewed the present state of knowledge concerning the physical mechanisms which are 